\title{
Water-Gas Shift Reaction: Advances and Industrial Applications
}

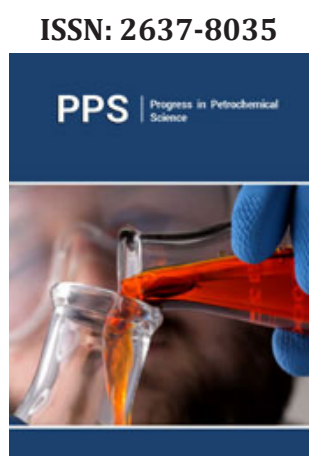

*Corresponding author: Makarand $\mathrm{R}$ Gogate, Independent Consultant for Ch.E Education and Research, India

Submission: 㭰 September 02, 2020 Published: 想 October 01, 2020

Volume 3 - Issue 4

How to cite this article: Makarand $\mathrm{R}$ Gogate. Water-Gas Shift Reaction: Advances and Industrial Applications. Progress Petrochem Sci. 3(4). PPS. 000569. 2020

DOI: 10.31031/PPS.2020.03.000569

Copyright@ Makarand R Gogate, This article is distributed under the terms of the Creative Commons Attribution 4.0 International License, which permits unrestricted use and redistribution provided that the original author and source are credited.

\section{Makarand R Gogate*}

Independent Consultant for Ch.E Education and Research, India

\section{Opinion}

In industry, the water-gas shift reaction (WGSR) describes the reaction of CO and water vapor to form $\mathrm{CO}_{2}$ and $\mathrm{H}_{2}$, the two principal shift products:

$$
\mathrm{CO}+\mathrm{H}_{2} \mathrm{O} \Leftrightarrow \mathrm{CO}_{2}+\mathrm{H}_{2} \quad \Delta{H^{o}}_{r}=-40.6 \mathrm{~kJ} / \mathrm{mol}
$$

As a stand-alone reaction, it is an important industrial reaction used in the manufacture of ammonia, to balance the $\mathrm{H}_{2} / \mathrm{CO}$ ratio, and provide pure $\mathrm{H}_{2}$ at the expense of $\mathrm{CO}$. It is also an important side reaction that occurs in parallel to the main synthesis reactions in conjunction with steam reforming of methane (over Ni-based catalysts), and methanol synthesis from $\mathrm{CO} / \mathrm{CO}_{2} / \mathrm{H}_{2}$ mixtures (over $\mathrm{Cu} / \mathrm{ZnO} / \mathrm{Al}_{2} \mathrm{O}_{3}$ ) [1-4]. The WGSR is also a critical component in reducing $\mathrm{CO}$ concentrations from feed gas streams in proton exchange membrane fuel cells (PEMFC). The Pt electrodes are highly susceptible to CO poisoning to levels as low as $1 \mathrm{ppm}$ $[5,6]$.

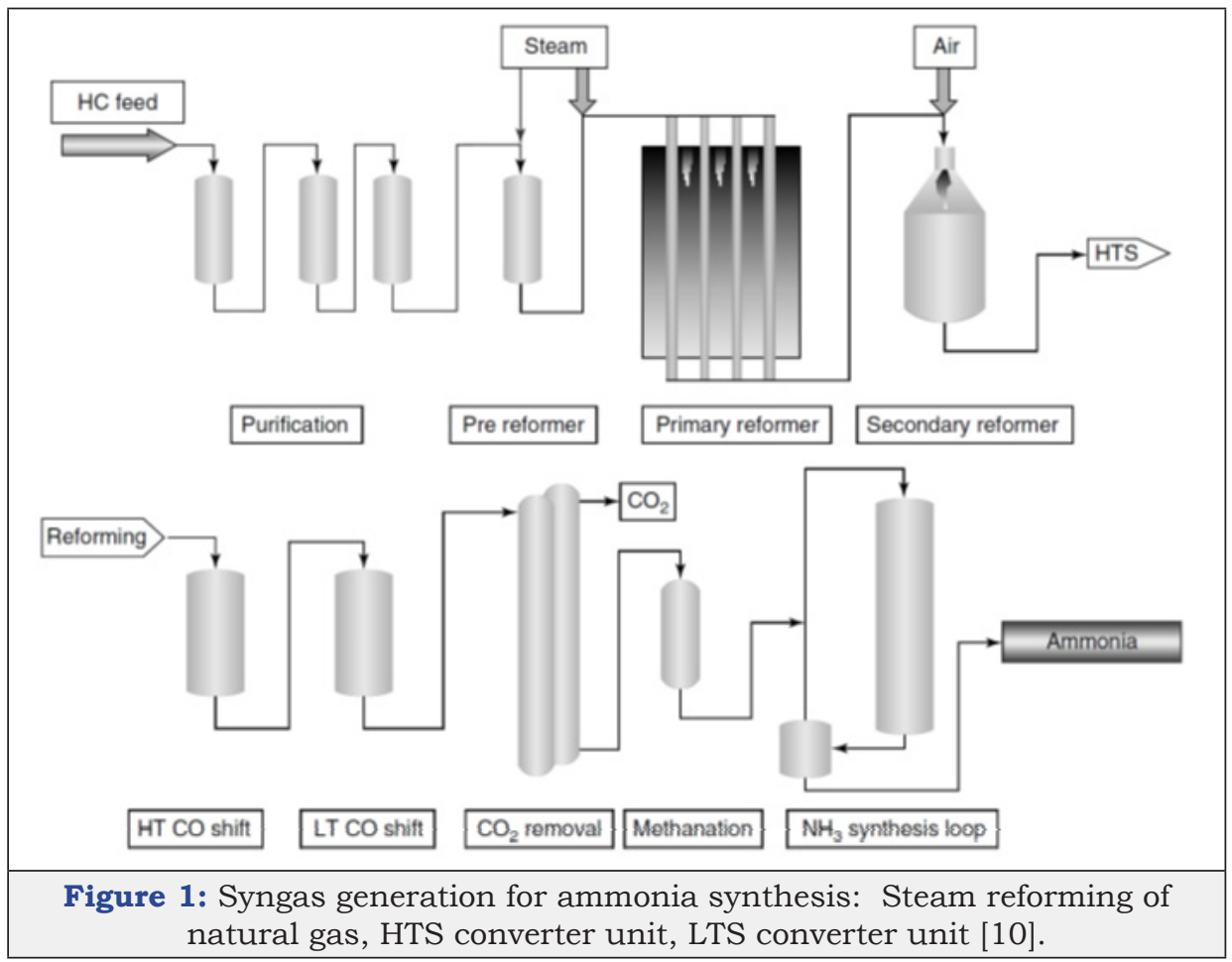

In most ammonia plants, the shift conversion is carried out in two stages: A high temperature shift (HTS) conversion unit, which converts typically $>80 \%$ incoming $\mathrm{CO}$, and a low temperature shift (LTS) conversion unit, which converts majority of remaining CO. 
The HTS converter is typically operated at $310-450{ }^{\circ} \mathrm{C}$, over a $\mathrm{Cu}$ promoted $\mathrm{Cr}$-Fe mixed metal oxide catalyst (with a composition of $88 \% \mathrm{Fe}_{2} \mathrm{O}_{3} / 9 \% \mathrm{Cr}_{2} \mathrm{O}_{3} / 3 \% \mathrm{CuO}$ ). At these temperatures, the shift reaction is in chemical equilibrium, and the concentration of $\mathrm{CO}$ at the reactor outlet is close to equilibrium levels, at $2-3 \%(\mathrm{v} / \mathrm{v})$ at $400{ }^{\circ} \mathrm{C}$. The LTS shift converter unit, over a commercial $\mathrm{Cu} / \mathrm{ZnO} /$ $\mathrm{Al}_{2} \mathrm{O}_{3}$ catalyst (methanol synthesis catalyst), then converts majority of remaining CO, to a concentration of $\sim 1000 \mathrm{ppm}$ (or, $0.1 \%$ ). The inlet temperature of the gas stream entering the LTS converter unit is typically in the range of $190-230{ }^{\circ} \mathrm{C}$ and is operated in the adiabatic mode [7-9]. Due to the adiabatic nature of operation and the exothermal reaction, the temperature at the converter outlet can reach $280^{\circ} \mathrm{C}$, and $\mathrm{CO}$ content is typically reduced to $<0.1 \%$. The schematic diagram of steam reforming (of natural gas) in series with the HTS and LTS water-gas shift conversion units, for syngas generation and purification for ammonia plants, is illustrated in Figure 1 [10].

The $\mathrm{Cu} / \mathrm{ZnO} / \mathrm{Al}_{2} \mathrm{O}_{3}$ WGS shift catalyst is highly susceptible to $\mathrm{S}$ poisoning, even at trace (or, ppb levels). Ahead of the LTS converter unit, a $\mathrm{ZnO}$ guard bed removes $\mathrm{S}\left(\mathrm{as}_{2} \mathrm{~S}\right.$ ) from the LTS inlet stream, typically operating at $370^{\circ} \mathrm{C}$. The concentration of $\mathrm{S}$ leaving the guard bed is typically $10-50 \mathrm{ppb}$, tolerant for the $\mathrm{Cu} / \mathrm{ZnO} / \mathrm{Al}_{2} \mathrm{O}_{3}$ shift catalyst.

We now consider and discuss the application of water-gas shift reaction for production of pure $\mathrm{H}_{2}$, for use in proton exchange membrane fuel cells (PEMFCs). As stated above, the concentration of CO leaving the LTS converter unit is typically $\sim 1000 \mathrm{ppm}$ or so (or, $0.1 \%$ ). However, for applications in PEMFCs (for portable power generation or transport applications), the Pt electrocatalysts are highly susceptible to poisoning by CO, to levels as low as $1 \mathrm{ppm}$. CO poisons the anodic Pt electrode through selectively adsorbing to Pt sites (akin to atom-specific CO chemisorption on $\mathrm{Pt}$ ); however, CO poisoning is also slow and reversible. As possible strategies for mitigation, the use of CO-tolerant Pt alloy particles (based on Ru-Pt core-shell nanoparticles), a higher operating cell temperature $\left(150^{\circ} \mathrm{C}\right)$, and use of oxygen co-feed in the fuel gas to the cell inlet, have all been proposed to combat the CO poisoning problem. In fact, the electrochemical oxidation of $\mathrm{CO}$, adsorbed on the Pt electrodes, the so-called "CO stripping" reaction, is one of the most widely studied electrochemical reactions [11]. In addition, perhaps a better strategy is to reduce the CO content of the inlet stream from about $1000 \mathrm{ppm}$ to $<1 \mathrm{ppm}$ before it enters the fuel cell assembly. A possible research advance in this area is the use of RuPt core-shell nanoparticles and catalysts based on Au (supported on $\mathrm{Fe}_{2} \mathrm{O}_{3}, \mathrm{TiO}_{2}$, etc.) for low temperature $\mathrm{CO}$ oxidation reactions [12-15]. The $\mathrm{Au} / \mathrm{TiO}_{2}$ system is exceptionally effective for catalysis of low-temperature $\mathrm{CO}$ oxidation reactions, even at temperatures as low as $0{ }^{\circ} \mathrm{C}$, mainly on account of a unique particle shape (hemispherical shape), and a narrow particle size distribution (for nanoscale systems prepared by the D.-P. method, with $\mathrm{TiO}_{2}$ Degussa P-25 support), with particle sizes in the range of $2.5-4.1 \mathrm{~nm}$. The unique particle shape and size leads to a very high metalsupport interfacial contact area, a structural motif that is rich in coordinatively unsaturated sites (cus sites with a low coordination number, $\mathrm{N}$ ), such as those at steps, corners, edges, and other planar/ border discontinuities. The effect of a low coordination number for $\mathrm{Au}$ is enormous: In contradistinction with adsorption/activation characteristics of planar, metallic $\mathrm{Au}$ for $\mathrm{O}_{2} / \mathrm{CO}$, the cus sites can result in a site-specific adsorption of over 13-orders of magnitude, at low temperatures $\left(\mathrm{O}^{\circ} \mathrm{C}\right.$ or higher $)$, with very high turnover rates and very low activation barriers $(<20 \mathrm{~kJ} / \mathrm{mol})$. Indeed, the grand universality of catalysis by nanoscale $\mathrm{Au}$ and application to catalysis of low-temperature $\mathrm{CO}$ oxidation reactions extends to other organic reactions of small molecules, including the watergas shift reaction, synthesis of vinyl chloride monomer, synthesis of hydrogen peroxide from $\mathrm{H}_{2}$ and $\mathrm{O}_{2}$, and others. As originally proposed and validated by further studies, nanoscale Au dispersed on suitable supports is an "uncommonly good" catalyst.

The production of pure $\mathrm{H}_{2}$ for use as in PEMFCs for streams containing very levels of $\mathrm{CO}$ require catalysts with exceptionally high activity at low temperatures. Under these conditions, the WGS equilibrium is favoured, and stoichiometric conversions and chemical selectivity to products can be attained. As discussed above, $\mathrm{Au}$ nanoparticles supported on a suitable oxidic support such as $\mathrm{Fe}_{2} \mathrm{O}_{3}, \mathrm{CeO}_{2}$, and $\mathrm{TiO}_{2}$, highly active for low-temperature CO oxidation reactions, are also exceptionally effective for lowtemperature water gas shift reaction [16-21].

\section{References}

1. Ratnasamy C, Wagner JP (2009) Water gas shift catalysis. Catal Rev: Sci Eng 51(3): 325-440.

2. Jacobs G, Davis BH (2007) Low temperature water-gas shift catalysts. Catalysis 20: 122-285.

3. Smith RJB, Muruganandam L, Murthy SS (2010) A review of water gas shift reaction kinetics. Int J Chem React Eng 8(1): 1-32.

4. Rebrov EV (2011) 13-Advances in water-gas shift technology: Modern catalysts and improved reactor concepts. In: Advances in clean hydrocarbon processing, Khan MR (Eds.), Woodhead Publishing, UK.

5. Wang Y, Chen KS, Mishler J, Cho SC, Adroher XC (2011) A review of polymer electrolyte membrane fuel cells: Technology, applications, and needs on fundamental research. Appl Energy 88(4): 981-1007.

6. Baschuk JJ, Li X (2001) Carbon monoxide poisoning of proton exchange membrane fuel cells. Int J Energy Research 25(8): 695-713.

7. National energy technology laboratory, Department of energy (2020) Water gas shift \& hydrogen production, USA.

8. Krishna RG, Smirniotis PG (2015) Water gas shift reaction: Research, development, and applications. In: ( $1^{\text {st }}$ edn.), Elsevier, Netherlands.

9. Lloyd L, Ridler DE, Twigg MV (1996) The water-gas shift reaction. In: Catalyst Handbook, Twigg MV (Ed.), ( $2^{\text {nd }}$ edn)., Manson Publishing, UK.

10. Ladebeck JR, Wagner JP (2003) Catalyst development for water-gas shift. In: Handbook of fuel cells: Fundamentals, technology, and applications. Vielstich W, Lamm A, Gasteiger HA (Eds.), Fuel cell technology and applications. John Wiley and Sons Ltd., UK 3(2): 190-221.

11. Klages M, Tjonnaas J, Zenith F, Halvorsen IJ, Scholta J (2016) Dual control of low concentration CO poisoning by anode air bleeding of low temperature polymer electrolyte membrane fuel cells. J Power Sour 336: 212-223.

12. Alayoglu S, Nilekar AU, Mavrikakis M, Eichhorn B (2008) Ru-Pt coreshell nanoparticles for preferential oxidation of carbon monoxide in hydrogen. Nat Mater 7(4): 333-338. 
13. Haruta M, Date M (2001) Advances in the catalysis of Au nanoparticles. Appl Catal A 222(1-2): 427-437.

14. Haruta M (1997) Size- and support-dependency in the catalysis of gold. Catal Today 36(1): 153-166.

15. Moreau F, Bond GC (2006) CO oxidation activity of gold catalysts supported on various oxides and their improvement by inclusion of an iron component. Catal Today 114(4): 362-368.

16. Carter JH, Hutchings GJ (2018) Recent advances in the gold-catalysed low-temperature water-gas shift reaction. Catalysts 8(12): 627.

17. Liang S, Veser G (2012) Nanocatalysts for the water-gas shift reaction. Nanomat Energy 1(3): 117-135.
18. Burch R (2006) Gold catalysts for pure hydrogen production in the water-gas shift reaction: Activity, structure, and reaction mechanisms. Phys Chem Chem Phys 8(47): 5483-5500.

19. Jacobs G, Davis BH (2007) Low temperature water-gas shift reaction. Catalysis 20: 122-285.

20. Fu Q Saltsburg H, Stephanopoulos MF (2003) Active nonmetallic Au and Pt species on ceria-based water-gas shift catalysts. Science 301(5635): 935-938.

21. Panagiotopoulou P, Kondarides DI (2006) Effect of the nature of the support on the catalyst performance of noble metal catalysts for the water-gas shift reaction. Catal Today 112(1-4): 49-52. 